\title{
'The barbarians themselves are offended by our vices': Slavery, sexual vice and shame in Salvian of Marseilles' De gubernatione Dei
}

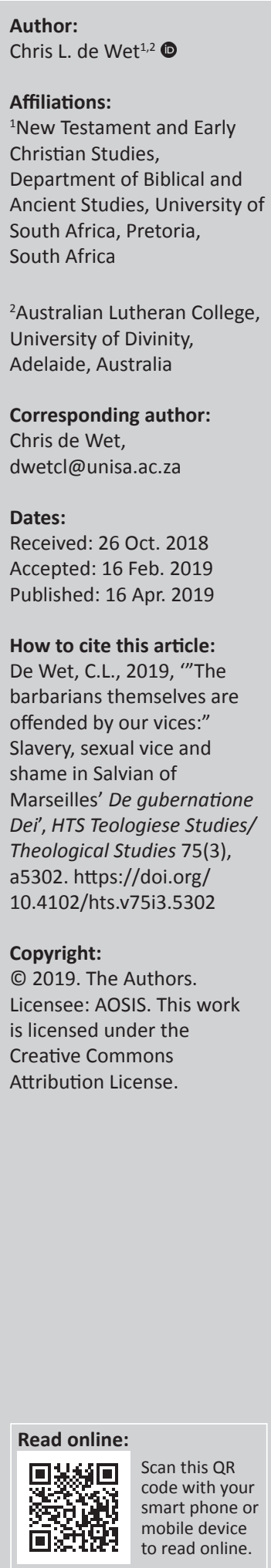

The purpose of this article is to examine Salvian of Marseilles' (ca. 400-490 CE) invective in De gubernatione Dei against his Christian audience pertaining to their sexual roles and behaviour as slaveholders. It is argued that rather than considering the oppressive practice of slavery in itself as a reason for moral rebuke and divine punishment, Salvian highlights the social shame that arose from the sexual vices Christian slaveholders committed with their slaves. Salvian forwards three accusations against his opponents that concern slavery and sexual vice. Firstly, he asserts that Christian slaveholders have no self-control. Secondly, the polyamorous relationships slaveholders have with numerous slaves resemble shameful and adulterous unions, namely concubinage and even polygamy. Thirdly, Roman-Christian slaveholders behave in a worse manner than barbarians (i.e. the argument of ethnicity). Each of these accusations is examined in detail in the study.

Keywords: Theology; Religious Studies; Church History; Early Christian Studies; Latin.

\section{Introduction}

By the middle of the 5th century CE, the Christian Roman Empire had experienced numerous calamities at the hands of the peoples surrounding the Roman provinces. In 410, the Visigoths under the leadership of Alaric sacked Rome, and in 439 Geiseric with a group of Vandals sacked Carthage. Two major cities of the empire had fallen at the hands of non-Romans, the so-called 'barbarians' (Heather 2006:191-299). The responses to these events, both Christian and nonChristian, are manifold. Among the former group, we have the Christian presbyter Salvian of Marseilles (ca. 400-490 CE), who wrote an incomplete treatise entitled De gubernatione Dei (GD; also known as De praesenti iudicio, most likely written sometime between 440 and 450 in the southern parts of Gaul). ${ }^{1}$ In this treatise, we read that many asked why God would allow the Christian Roman Empire to suffer in such a manner under the barbarians, when in its 'pagan' past the empire was at its height (Brown 2012:444-445). According to Salvian, some were of the opinion that God had withdrawn from human affairs and no longer showed any care for what happens on earth. 'By certain men God is said to be careless and neglectful of human actions, on the ground that he neither protects good men nor restrains the wicked', Salvian writes as the opening words to $G D$, 'and they claim that this is why at the present time the good are generally wretched and the wicked happy' (GD 1.1.1; Lagarrigue 1975:100; transl. Sanford 1930:36). ${ }^{2}$ The question of theodicy is, therefore, central to GD. Why would God allow suffering to occur in an empire that was characteristically Christian?

Salvian's answer to this was that the current torments of the empire are in fact a just, even merciful, punishment from God for the social and moral turpitude of the time (GD 4.2.10; Lagarrigue 1975:238-240).

The fact that wicked cities are sacked should come as no surprise to persons who know the Scriptures. These events are, in fact, indicative of a God who is involved in human affairs.

1.For the Latin critical text of $G D$ (which is used in this study) and a French translation, as well as issues of Salvian's background, and the provenance and dating of GD, see Lagarrigue (1975:11-15). On the manuscript tradition of GD, see Vecchi (1951). In most cases, the English translation of Sanford (1930) will be used (because the entire work is more accessible to readers), with slight adaptations in some marked instances. A further helpful introduction to and English translation of GD can be found in O'Sullivan (1962:3-17). On the role of Salvian in the reconstruction of late antique history, see Badewien (1980:3-16) and Elm (2017:1-28). For a structural outline of GD, see Sanford (1930:4-7).

2.Translation slightly adapted.

Note: The collection entitled 'Eben Scheffler Festschrift', sub-edited by Jurie H. le Roux (University of Pretoria) and Christo Lombaard (University of South Africa). 
The rhetoric of punishment in GD, however, is very specific. Among several other rhetorical tropes, the motif of slavery truly stands out when reading the treatise. Salvian writes in GD 4.2.9-10 (Lagarrigue 1975:238-240):

Why do you wonder that we are chastised, that we are given over into the hands of the enemy, that we are weaker than all other men? Our miseries, our infirmities, our overthrow, our captivities and the punishments of our evil slavery [improbae seruitutis] are the proof that we are bad slaves [mali serui] of a good master [boni domini]. How are we bad slaves? Because, to be sure, our sufferings are only in proportion to our deserts. How are we the slaves of a good master? Because he shows what we deserve, even though he does not inflict on us the punishment due, for he would rather correct us by the most kind and merciful chastisement than permit us to perish. As far as our misdoings are concerned, we deserve the penalty of death, but he, attaching more importance to mercy than to severity, prefers to better us by mercifully tempering his censure, than to slay us by the infliction of a just chastisement. (transl. Sanford 1930:80)

The discourse of slavery, or doulology (De Wet 2015:1-44), is therefore used to extrapolate the dynamics of God's punishment. Thus, God's punishment, Salvian argues, is like a good and just master punishing his wicked and degenerate slaves. Christians have failed to act as good and obedient slaves of God, ${ }^{3}$ and Salvian argues that they are even worse than the basest of 'real' institutionally enslaved persons. What we know of Salvian's background may explain why he uses doulology so often in GD. He most likely came from the wealthy aristocratic landowning elite, as he exhibits much knowledge about life on the villa estates of the Western Empire (Lagarrigue 1971:10-11). Although he was never a bishop, he did move in the circles of the upper echelons of the Christian elite and seems to have been involved in theological education and in some sacerdotal duties (Sanford 1930:13). Undoubtedly, Salvian grew up in a household where there were slaves and from the fact that he adheres to certain ideal practices of mastery, as will be shown in the study, there is no reason to doubt that he himself owned slaves. The question of who the slaves to whom Salvian refers were is a more complicated matter. The slaves in GD included domestic and agricultural slaves (included in terms like servi, ancillae and familia ; Samson 2002:218-227), but most likely also non-free coloni, as Goffart (2009:269-288; see also Alföldy 2014:191) has convincingly shown (see also Bradley 2005). In the case of slaves who are violated as sexual objects, the focus is most likely on domestic slaves, who were in close proximity to the master (dominus) of the household.

In this article, I will examine Salvian's invective in GD against his Christian audience pertaining to their sexual roles and behaviour as slaveholders. It will be argued that instead of considering the violent and oppressive practice of slavery in itself as a reason for rebuke, Salvian focuses on the social

3.On the metaphor of the slavery to God, see especially Martin (1990:50-85), De Wet (2018:1-39) and Kartzow (2018:1-46).

4.For servi, see GD 4.2.9-10, 4.5.24-25, 7.3.16, 7.4.19; for ancillae, see GD 4.5.25 7.3.16; for familia, see GD 4.5.24. Samson (2002:218-227) provides a more detailed examination of the terminology. shame ${ }^{5}$ that arises from the sexual vices slaveholders commit with their slaves. We do know that the sexual violation of slaves (women and men) was a common characteristic of late ancient slavery (Harper 2011:281-325), and with the rise of early Christianity, the issue of slave sexuality became even more controversial and complicated (Gaca 2003:219-306; Glancy 1998). Salvian makes it clear in GD 1.1.1 (Lagarrigue 1975:100) that he writes the treatise for a Christian audience, which means that the comments about mastery and slavery in GD highlight practices that most likely occurred in Christian households and villas. Let us begin by investigating Salvian's accusations against some slaveholders in his audience more closely.

\section{Slavery, sexual vice and shame in De gubernatione Dei}

Salvian's polemic in GD is generally directed against rich and elite Christian landowners and slaveholders.

Using various stereotypes related to slaves, he shames his audience into admitting that they are more degenerate than their own slaves. If real slaves are often robbers and liars (GD 4.3.14; Lagarrigue 1975:242), then the rich are even more guilty: 'You think theft a servile fault, but you too, O rich man, commit robbery when you encroach on things forbidden by God; every man who performs illicit actions is guilty of theft' (GD 4.3.19; Lagarrigue 1975:246; transl. Sanford 1930:82). If real slaves are prone to running away from their masters (GD 4.3.15; Lagarrigue 1975:242-244), then the rich slaves of God even more so. 'If a slave is a runaway, so are you also, rich and noble though you are, for all men who abandon the law of the Lord are running away from their master' (GD 4.3.18; Lagarrigue 1975:246; transl. Sanford 1930:82).

The case of the rich is even more shameful, as real slaves may possibly be fleeing from bad masters or from cruel overseers, while the rich ones to whom Salvian refers flee from a divine Master who is just and merciful. These 'servile vices', or uitia seruorum (GD 4.3.13-6.29; Lagarrigue 1975:242-249), were common characteristics in registers of doulological stereotypes. ${ }^{6}$ When Salvian applies them to the rich elite there is a sense of great irony and shame because these slaveholders expect their own slaves to be obedient, yet they fail in their obedience to their heavenly Master.

But Salvian does not simply question the ability of the elite to be good slaves of God. He is also very critical of their mastery over their own slaves. The elite are not only bad slaves of God, but they are even worse masters of their own slaves. Salvian often criticises the slaveholding practices of the elite, such as not giving enough food to their slaves or entrusting

5.Honour and shame were central and socially structuring values in the ancient Mediterranean world. Attaining honour and avoiding shame were key to ideal Roman identity and an individual's behaviour, especially if such an individual came Roman identity, and an individual's behaviour, especially if such an individual came from the elite classes, was dictated by the socially and religiously determined norms of honour and shame (Barton 2001:202-269). Sexual shame and shaming were also
very common rhetorical techniques in Roman antiquity (Knust 2006:15-50).

6.On the use of vice lists more generally in early Christianity, see Vögtle (1936) and McEleney (1974:203-219). On the use of slavish vices and morals in Salvian's understanding of education, see the helpful article of Opelt (1974:54-61). 
them to cruel and unjust overseers. What especially stands out in GD are the sexual transgressions of the slaveholding elite against their slaves. Three points of invective may be deduced from the sections in GD that concern slavery and sexual vice, namely (1) Christian slaveholders have no selfcontrol; (2) the polyamorous relationships slaveholders have with numerous slaves resemble shameful and adulterous unions, namely concubinage and even polygamy, and (3) Roman-Christian slaveholders behave in a worse manner than barbarians (i.e. the argument of ethnicity).

\section{The lack of self-control among Christian masters}

Despite some social stigmas, all slave bodies in late antiquity, both male and female, were open to sexual violation without any formal legal protection. For many slaves, rape was a fact of daily life. Furthermore, slaves were also often forced to procreate or 'breed' so as to increase the slave bodies owned by the slaveholder (children born from slave women automatically became the property of the owner). ${ }^{7}$ Slave procreation had economic benefits. Thus, slaves had absolutely no sexual honour (pudicitia) (Glancy 2006:21-24; Harper 2013:23-26). The freeborn state, on the contrary, was synonymous with sexual honour and modesty. These states of honour were especially visible in the women who embodied them. The slave woman, or ancilla/serva, was considered to be the opposite of the honourable free woman, or matrona.

Furthermore, slavery and prostitution practically overlapped in late antique Roman society (McGinn 1998:345). Public prostitutes working in brothels were often slaves or freedwomen, and slaves in households were often considered as 'private prostitutes' (Perry 2013:29-37).

Not much changed when Christianity became the favoured religion, and eventually the state religion, of the Roman Empire. Christian society accepted and benefited from slavery, but aimed to sustain a slaveholding ethos and system according to certain Christian values. It has already been shown (De Wet 2015, 2018; Glancy 2006) that some of the fundamental elements in early Christian discourse in fact sustained slavery.

Salvian did not take issue with the fact that Christian masters owned slaves. He is rather concerned with the way in which they dominated their slaves. Contrary to ancient Roman tradition, household slave women were not supposed to be used as prostitutes, according to Salvian. The fact that married men had sexual relationships with slaves, or women of servile rank, as Salvian says, disturbs him the most (GD 4.5.24; Lagarrigue 1975:250; transl. Sanford 1930:84):

What rich man keeps his marriage vows, who among them does not plunge headlong into passionate lust, who does not use his

7.Regarding the sources and possible numbers of slaves in the Roman Empire, see Scheidel (1997:156-169), but note a critical caveat from McKeown (2007:124-140) not to be misled by numbers, and on the general possibilities and limits to what he calls 'scientific' (i.e. empirical) approaches to the study of ancient slavery. household slaves as harlots and pursue his madness against any one on whom the heat of his evil desires may light? They illustrate well the words of the Holy Scriptures about such men as they: 'They have become as stallions rushing madly on the mares'. (Jer 5:8)

Mastery, self-mastery in particular (dominium; disciplina), is what defined Roman honour in antiquity (Barton 2001:18). In this section, Salvian presents a very common invective against his opponents. He shames them, sexually, by advancing the point that these elites have excessive and unbridled sexual lust.

Lust was seen as the result of bodily heat, but in these 'rich' persons, the 'heat of evil desires' has become so excessive that it drives them mad. They are no longer rational, as men were expected to be, but are now in a very unmasculine state of sexual frenzy. Moreover, Salvian animalises his opponents. Referring to Jeremiah 5:8, he asserts that these men no longer act in a rational and human manner, but are like animals heated stallions, in fact - who have no reason.

Salvian's arguments on the sexual violation of slaves by their Christian masters in GD serve to demonstrate that those who were supposed to govern, the wealthy freeborn and elite males of society, were themselves in relationships where they were enslaved to their passions. Their indulgence in luxury and sexual excess proves that they are unable to master themselves. And when one is unable to master oneself, one easily slips into a servile state and becomes consumed by servile vices. In ancient Christian thought, a slave was in such a state because he or she was unable to master him- or herself, as we see, for instance, in Basil of Caesarea's statement in De spiritu sancto 20.51.11-20 (Pruche 2013:428-430): 'It is better for a person who lacks intelligence and self-control to become another's possession'. The excessiveness of the lust of these elite men is further betrayed in the number of women with whom they have relationships. In this regard, the issue of concubinage arises repeatedly in $G D$, which we shall shortly address. Salvian's accusation of the lack of self-control is therefore ironic. The men who were supposed to exercise control and domination over their subordinates are unable to even control themselves. Society is therefore turned upside-down. Masters appear to have become slaves themselves.

\section{The socio-sexual problems of polyamory: Concubinage, polygamy and adultery}

In GD 4.5.25-26, 7.3.16-17 and 7.4.19-20, we find the most vehement rhetorical assaults from Salvian against his audience relating to their sexual transgressions with their slaves. In these sections, Salvian points out that some lecherous slaveholders have forgotten the honour and sanctity of marriage, making them adulterers. The slaveholders now engage in relationships that are so polyamorous that these 'unions' resemble concubinage and even polygamy. To understand the thrust of Salvian's 
arguments, I will first discuss, briefly, the dynamics between slavery, marriage, adultery and concubinage.

The exclusion of slaves from the realm of pudicitia is evident in the fact that the enslaved in Roman society were not eligible for marriage. Although slaves formed unions, called contubernia, these unions did not merit the same respect and benefits as a marriage between free persons (Cohick 2009:261262). The legal implication of this principle is that, technically, when a man sexually violates a slave it was not considered to be adultery (adulterium). If a man had sex with a slave or a prostitute, it was not even considered stuprum, a type of misconduct slightly less serious than adultery (unless the slave belonged to someone else, which would then be more a case of damage to property). ${ }^{8}$ However, when freeborn women had sexual relations with anyone except their husband, including slaves, they were indeed guilty of adultery (De Wet 2015:220-224). Male adultery is not a concept found in Roman law. Adultery was defined by the standard of a married woman having a sexual relationship with a man who is not her husband (Sessa 2018:95).

Needless to say, freeborn Roman men had a greater deal of sexual freedom than women.

Although men could not legally be found guilty of adultery, Christian writers and preachers admonished their congregants that divine law, Scripture that is, does hold a man responsible. In fact, the scope of sexual misconduct, or stuprum, was expanded in Christian thought to include the violation of slave girls, contrary to Roman law (De Wet 2015:230-231). Moreover, in many cases stuprum was equated with adulteria if a married person, man or woman, was involved. For instance, in a homily solely devoted to the problem of fornication and adultery (referring to 1 Cor 7:2), John Chrysostom states (Propter fornicationes autem unusquisque suam uxorem habeat 4; Migne 1862:51, 213-214):

For we are not ignorant of the fact that many consider it adultery only when someone should sexually violate a married woman. But I, myself, am saying that it is adultery all the same when one has sex with any woman - whether she is openly a prostitute, a slave girl, or any other woman without a husband - it is wicked and concupiscent. For it is surely not only from the ones who are being violated, but also from the ones who violate, that the accusation of adultery is contracted. And do not mention to me now extraneous laws that drag wives who have been adulterized into courts of law demanding an account, but not demanding an account when those having husbands and wives are seduced by the slave girls. But I will read to you the law of God, which is similarly displeased with both wives and husbands, saying that the act is adultery. (transl. De Wet 2015:231)

A man is now held guilty of adultery in all cases of sexual misconduct, including violating slave girls or engaging in prostitution. A contemporary of Chrysostom, the bishop Ambrose of Milan, makes a similar statement: 'Any sexual offense [stuprum] is adultery [adulterium], it is lawful neither 8.For a more thorough discussion of the legal category of stuprum, see taiou (1993:113-133). for a husband or a wife' (De Abraham 1.4.25; Migne 1845:14:452; see also De Wet 2015:231; Kuefler 2001:165).

Concubinage (concubinatus), in late ancient society, referred to a living arrangement between partners 'whose status denied a legal union' (Sessa 2018:94). It was, therefore, a type of 'common law marriage' between persons of different status, which did not hold the benefits of a formal Roman marriage, specifically in relation to the status of the children born from such unions (who received the mother's status) and in relation to issues of inheritance (Hersch 2010:27-28). The woman who was usually the socially inferior party in the relationship was known as a concubine. In Latin, there is no word for a male concubine-concubinatus meant concubinage, and the term 'concubine' was written in the feminine form, concubina.

Concubinage was legal in the Roman world, and although it was frowned upon by many, including some Christian writers, it was not necessarily a taboo in and of itself (Grubbs 1999:309-316). Augustine, most famously perhaps, had a relationship with a concubine, with whom he had a son, before he became a bishop (Brown 1967:50-51). Although it was legally forbidden for a man to have a concubine while being married to another (Kiefer 2012:50), many elite men had wives and concubines. From a Roman legal perspective, it should once again be remembered that a man who had a relationship with a concubine, even while he was married, was not legally guilty of adultery. However, from a Christian perspective, as noted above, any sexual relationship outside of marriage, including with a concubine (while one is married to another), could be classified as adultery.

Slaves and freedwomen could be concubines (Harper 2011:315), although when a master had a relationship with a slave it did not by default imply concubinage. Concubinage was a slightly more formal and lasting agreement between two parties, and a union of concubinage had to be reported to the authorities. As Harper rightly notes, the 'line between concubinage and the sexual use of household slaves is harder to distinguish. When late antique men spoke, the two practices were often blurred' (Harper 2011:315). Technically, slave men could not take their own 'concubines' without formal permission from the owner, but in this case such a union would be a contubernium, a type of union very similar to concubinage, but reserved for cases when both parties were slaves (Cohick 2009:260-261).

Having delineated the basic premises that structured sexual misconduct, adultery and concubinage in Roman society, let us continue to examine the relevant sections in GD. In the first instance, Salvian (GD 4.5.25-26; Lagarrigue 1975:252) says that some rich men have so many relationships with slave women that:

[t]o use the term concubine [concubinis] may perhaps seem unfair, since in comparison with the vices mentioned above it seems almost a form of chastity to be content with a few mates and restrain one's lusts to a fixed number of wives. I say 'wives' 
[coniugum] advisedly because we have come to such a pass that many consider their maidservants [ancillas] as actual wives [uxores]. Would that they were content to have only those whom they do so consider! But the truth is more foul and loathsome by far - for certain men who have contracted honourable marriages take additional wives of servile rank, deforming the sanctity of holy matrimony by low and mean unions, not blushing to become the consorts of their slave women, toppling over the lofty structure of marriage for the vile beds of slaves [seruarum], proving themselves fully worthy of the rank of those whom they judge worthy of their embrace. (transl. Sanford 1930:84)

We encounter some difficulties with this passage. Firstly, Salvian seems to imply - somewhat tongue-in-cheek - that the licentious rich elites are engaging in sexual relations with so many women that it has exceeded the bounds of concubinage. Roman law usually speaks of concubinage in the singular (see, for instance, the lists compiled by Grubbs 2002:171-180), but as Harper (2011:314-320) has shown, some men may have been rather liberal with concubines, and the blurred distinctions between concubines and slave girls (concubines were more often freedwomen) may imply that some men had multiple concubines.

Because of the formality and public nature of concubinage, and the legal prohibition of having a wife and a concubine, it may be that having few or no concubines would be, socially at least, more acceptable. But when an elite man attaches himself to many slave girls in sexual relationships, he himself becomes servile.

But we should understand Salvian's rhetoric here less literally. He seems to imply that the rich elite are not choosing the lesser of two evils, and the legally and socially constructed boundaries that governed relationships between men and women, whether in marriage or concubinage, are totally destabilised by these men who simply cannot have enough sexual partners. Their lifestyles resemble polygamy to Salvian.

Just as Chrysostom and Ambrose reduced all instances of stuprum to adulteria, so does Salvian, albeit ironically, reduce all sexual unions to marriage, making his opponents polygamists. Roman law explicitly prohibited polygamy (Grubbs 2002:185), and it also prohibited marriage between freeborn persons and slaves. But what is essentially taking place, in Salvian's mind, is elite men engaging in polygamy with slave women; hence, it was a combined instance of sexual vice. The excessive lust of the rich elite has destabilised social structures, according to Salvian.

Not only are social structures destabilised by elite men cavorting with slave girls, but individual social identities lose their meaning and significance. Salvian states (GD 7.3.16-17; Lagarrigue 1975:440-442):

Who honoured his wife by a faithful observance of his marriage vows? No, as far as passive endurance of their lust is concerned, who among them did not reduce his wife to the status of his maidservants [ancillarum] and degrade the sacrament of holy matrimony so far that no woman in the house was made to seem more contemptible by her husband's conduct than she who was made chief in it by the dignity of marriage? Perhaps some one is thinking that what I say is not strictly accurate; for the matrons of southern Gaul did continue to exercise their rights and to hold honour [honorem] and power [potestatem] as mistresses [dominarum] of their households. That is true. Many of them indeed did keep unimpaired their right of government [dominii], but scarcely one kept her marriage rights unpolluted. Our present object of investigation is not the power of women, but the infamous conduct of their husbands. However, I should not even say that the matrons kept their power uninjured, since a wife who has not kept her connubial rights safe and inviolate has not kept her full rights of domination [dominii]. When the master of the house [pater familias] acts as husband [maritus est] of the maidservants [ancillarum], the mistress [matrona] is not far removed from the mean position of the slave [seruarum]. (transl. Sanford 1930:144)

For Salvian, the power of mastery, or dominium, of the matrons - who were traditionally seen as the polar opposite of a slave girl - is ruptured when their husbands fornicate with persons of servile status. The logic, therefore, stands that once all sexual relationships are made akin to 'marriages' of some sort, and all instances of sexual misconduct become adultery, there can be no stable measure of conjugal or domestic dominium. A major problem for Salvian, it seems, is that by engaging in these sexual relationships with slaves, to the point of practically considering them as wives, the boundaries of power and domination are rendered opaque. No longer are masters and mistresses dominating their slaves, but by having so many servile sexual partners, the masters exhibit themselves as being dominated by slaves. This disequilibrium of kyriarchal power may also be the reason why Salvian refers to concubinage. Concubinage was technically, but not always practically, a formal and asymmetrical relationship where the power dynamics were clearly defined. Harper (2011:317) states: 'Concubinage was thus a direct continuation of the master's power'. The problem with having sexual relationships with slave girls was that it was informal and blurred the dynamics of power. Thus, the rot of the Christian Empire starts at the head, the head of the household, or the paterfamilias (GD 7.4.19-20; Lagarrigue 1975:444):

Since this is the case, I ask the wise what sort of families they think were found where such men were heads of the households [patres familias]? What corruption do they think there would be among the slaves [seruorum], where there was such great vice among the masters [dominorum]? For if the head is diseased no part of the body is sound, and no member performs its functions when the dominating part is not functioning. Moreover, the master's relation to his house is that of the head to the body, its very life, setting up standards of living for all its members. The most unfortunate aspect of the matter is that all follow the worse example more readily, and evil associations corrupt good manners more easily than good ones will correct the evil. Furthermore, since even good and honourable heads of families cannot make their slaves good, what do you think becomes of the household morality when the master himself sets an example of lewdness? And yet in such a case we have not only an example of immorality but a sort of enforced necessity, since the slave 
women are compelled to obey their wanton masters against their will, and the lust of those in power is the compulsion of their subjects. From this we may see how great was the filth of shameless vice when women subject to the most depraved of masters were not allowed to be chaste even when they wished. (transl. Sanford 1930:144)

In early Christian thought, masters were responsible for teaching their slaves virtue. This was not a wholly novel or uniquely Christian concept (some Stoics, for instance, also believed slaves should be taught virtue), but it was clearly articulated in early Christian teaching (De Wet 2015:190-195). This principle goes against the traditional stereotype that slaves are unable to be virtuous because they cannot act rational in an authentic way (when slaves acted rationally, it was seen as an act of mimicry) (DuBois 2008:157-165). What is even worse, we find, is that some slaves who wanted to be chaste were forced to fornicate by lewd masters. The figure of the chaste slave woman, like that of the reformed and penitent prostitute (Harper 2013:222-228), was very important in early Christian rhetoric.

\section{Slavery, sexual vice and ethnicity in De gubernatione Dei}

When women, slave women especially, were shown to be masters of virtue, and even likened to philosophers as Chrysostom did (Homilia 42 in Acta Apostolorum 4; Migne 1862:60:301), it was considered an accolade of Christian identity, often in opposition to 'pagan' or Greek philosophy. Chrysostom was proud that Christian slave women acted with the same virtue as elite freeborn men. But Salvian now forwards the same logic in the opposite direction - freeborn Christian men are no better than slave girls, and this means that Christian identity and philosophy are disgraced by these individuals. It is so that even 'the barbarians themselves are offended by our vices' (GD 7.6.24; Lagarrigue 1975:448; transl. Sanford 1930:145). Ethnicity, especially what defines Romanness, is a central motif in GD.

Traditionally, in Roman thought, barbarians were often considered to be sexual deviants. Roisman (2014:403) states that 'a tendency to find barbarians lustful is commoner among Roman writers and Greek writers of the Roman era than among their Greek predecessors'. However, Roisman (2014:403-406) also proves that the use of barbarian sexuality as a shaming device was equally common in this period. Salvian is, therefore, by no means unique when he appeals to ethnosexuality in GD. This does not imply that Salvian's rhetoric is pro-barbarian (for instance, heretics are included among the barbarians, as shown below). He firmly relies on barbarian stereotypes to make various points. For instance, Salvian states (GD 4.14.67-68; Lagarrigue 1975:286):

There is this difference between us, that even if the barbarians do the same things that we do, our sins are still more grievous than theirs. For our vices and theirs can be equal without their guilt being as great as ours. All of them, as I said before, are either pagans or heretics. I shall discuss the pagans first, since theirs is the older delusion: among these, the nation of the Saxons is savage, the Franks treacherous, the Gepids ruthless, the Huns lewd - so we see that the life of all the barbarians is full of vice. Can you say that their vices imply the same guilt as ours, that the lewdness of the Huns is as sinful as ours, the treachery of the Franks as worthy of accusation, the drunkenness of the Alemanni as reprehensible as that of Christians, the greed of an Alan as much to be condemned as that of a believer? (transl. Sanford 1930:95)

It is not the case that the barbarians are all noble, but that Roman-Christian society has become barbarous in itself. The punishment on Christian society is worse, according to Salvian, because God's truth has been revealed to them. In book 7 of GD, Salvian repeatedly refers to the sexual vices slaveholders commit with their slaves, as we have seen throughout this study. In the same sections of GD 7, he also repeatedly states that the barbarians do not commit such sexual sins. Salvian seems to imply that barbarians honour marriage and monogamy more than the Roman Christians (GD 7.6.24-7.27; Lagarrigue 1975:448-450):

Consequently, even if a man lives among unchaste barbarians, he ought to seek chastity, which is of service to him, rather than lewdness, which pleases his lustful enemies ... Among the Goths no one is permitted to indulge in fornication; only the Romans in their land, by national and titular prerogative, are allowed this vice. What hope, I ask, have we then in the sight of God? We love vice, while the Goths execrate it; we flee from purity, while they love it; fornication with them is a perilous vice, but with us a mark of honour. Do we think that we can stand before God, do we think that we can attain salvation, when every crime of impurity, every disgraceful vice, is committed by the Romans and censured by the barbarians? At this point I ask those who consider us better than the barbarians to tell me which of these evils are committed by even a very few of the Goths, and which of them are not committed by all or nearly all of the Romans? Yet we wonder that the lands of the Aquitanians and of us all have been given by God to the barbarians, though those same barbarians are now purifying by their chastity the places polluted by the fornication of the Romans ... In the captivity of Spain God wished to give a twofold evidence of his hatred of carnal lust and love of chastity, when he put the Vandals in command solely on account of their preeminent chastity and subjected the Spaniards to them solely on account of their surpassing lewdness. (transl. Sanford 1930:145)

Salvian's knowledge about Huns and Goths was probably from their presence in the Roman army (Maenchen-Helfen 1973:262), while he may have seen at a young age Vandals and Alans cross the Rhine (Brown 2012:444-445). Barbarians were no strangers in Gaul. Many of these non-Romans were already Christianised. On the one hand, we see that he acknowledges that some barbarians, like the Huns, are known for their lewdness. On the other hand, he also states that some groups, like the Goths, abhor sexual vice. These claims are, of course, difficult to verify. On the one hand, evidence about Gothic sexuality, for example, is sparse, and on the other, Salvian is probably more reliant on stereotypes and anecdotes than actual facts. We should not assume, as Salvian seems to imply, that the 
barbarian invasion of Roman territories was a type of 'holy' occupation that enforced sexual chastity onto the inhabitants. Salvian's argument is rhetorical, and should not be seen as an accurate historical reflection of barbarian sexuality - he implies, ironically, that those who were formerly and stereotypically considered unchaste, without self-control, and lewd are now bringing chastity to Roman society. Elm (2017:1-28) has argued that Salvian, in GD, asserts that Christians have lost the solemn right to be called Roman, and that the 'New Romans' are the barbarians, to whom God has given the new right of dominium. However, the loss of Christian imperial dominium is related to the inability of Christian elites to master themselves and their subordinates, especially slaves. Because of the disregard of domestic dominium, Christian elites have lost the privilege of political dominium. This is the point made by Salvian. Brown (2012) rightly states:

For Salvian, this series of unexpected conquests seemed to hang together in a single, dramatic pattern. They [the barbarians] were the footsteps of God as He strode in judgment across the West in the here and now. (p. 445)

\section{Conclusion}

Although, at face value, GD seems apologetic towards slaves and antagonistic towards unjust masters, it is by no means an abolitionist tract. GD in fact petitions for a very specific mode of slaveholding that Salvian considers to be ideally Christian. As an elite male himself, Salvian does not conceive of an ideal society as one without slaves. Rather, an ideal Christian society is one in which the dynamics of power, of dominium, are clear. In the first instance, elite Christians fail as slaves of God. It is impossible to separate Christian discursive and metaphorical constructs of divine slavery from their views and practices as real slaveholders (De Wet 2018:9-20; Kartzow 2018:1-46). They resemble bad slaves of a good master - they comply with all the servile vices associated with the negative slave stereotype. They are robbers, liars, runaways, and even murderers and fornicators. By asserting themselves and being disobedient to God, these wicked slaves of God attempt to destabilise one of the most important power relationships, namely that between God and human beings. Therefore, God also punishes them by making them subjugated to barbarians. The punishment of God against the Christian Roman Empire, in Salvian's thought, is a restoration of divine dominium.

The inversion of the power relationship between God and his slaves is mirrored in society, especially when elite Christian men engage in sexual relationships with and violation of slave women. Following mainstream Christian thought, Salvian considers all extramarital sexual relationships as adultery. Although he goes even further by saying that elite Christian men take slave girls not as concubines or even prostitutes, but as 'wives'. This denoted a sexual relationship that entails an exchange of power, which results in, according to Salvian, a close equivalent to 'marriage'. His rhetoric is hyperbolic, yet the reason he uses the term 'wife' to describe the role of the slave woman in such a relationship is because of the destabilisation of power resulting from such 'unions'. It is not asymmetrical and formal like concubinage, which is in itself not the ideal. The matron is robbed of her honour and dominium, and the husband seems to be dominated by his subjugates. The inversion of kyriarchal power through forbidden sexual relationships is transposed to signify the total disarray of whole social order. The destabilisation of the acceptable social order is what results in the shame and shaming of the Christian elite men.

Salvian's ideal Christian mode of slaveholding entails a dominium that rests solely with the master and the mistress. There should be no extramarital sexual relationships with anyone, slave or free, and slave sexuality should be strictly regulated. Like most Christian authors of late antiquity, he assumes that masters are responsible for teaching their slaves virtue, and that slave women are in fact capable of being chaste (contrary to popular opinion and parlance). Rather than indulging in sexual vice and leading their slaves into forbidden sexual relationships, ideal Christian masters should be examples of chastity to their slaves and teach them virtue.

In conclusion, we should be wary of understanding Salvian's ideal Christian mode of slaveholding as being less oppressive. Although it is a positive step to dissuade masters from sexually violating their slaves and forcing them into relationships, there still remains a strict control of slave sexuality, and the disciplinary domination that had to sustain 'chaste' slaveholding did not necessarily assume techniques that were less oppressive than those underlying a sexually abusive slaveholding disposition. The slave still remains universally disempowered and depersonalised. Christian rhetoric pertaining to the sexuality of slave women sustained the institution of slavery at its very core by asserting that it was 'virtuous' and invested in keeping these women 'chaste' - but the price of chastity for slave women came at the same high cost as their sexual violation, namely a surrender of their bodies and, in essence, their subjectivity as human beings.

\section{Acknowledgements Competing interests}

The author declares that he has no financial or personal relationships which may have inappropriately influenced him in writing this article.

\section{References}

Alföldy, G., 2014, The social history of Rome, Routledge, London.

Badewien, J., 1980, Geschichtstheologie und Sozialkritik im Werk Salvians von Marseille, Vandenhoeck \& Ruprecht, Göttingen.

Barton, C.A., 2001, Roman honor: The fire in the bones, University of California Press, Berkeley, CA.

Bradley, K.R., 2005, The Snowden lectures: 'The bitter chain of slavery': Reflections on slavery in ancient Rome, Center for Hellenic Studies, Harvard University, viewed 26 September 2018, from http://nrs.harvard.edu/urn-3:hlnc.essay:BradleyK.The Bitter_Chain_of_Slavery.2005 
Brown, P., 1967, Augustine of Hippo: A biography, University of California Press, Berkeley, CA.

Brown, P., 2012, Through the eye of a needle: Wealth, the fall of Rome, and the making of Christianity in the West, 350-550 AD, Princeton University Press, Princeton, NJ.

Cohick, L., 2009, Women in the world of the earliest Christians: Illuminating ancien ways of life, Baker Academic, Grand Rapids, MI.

De Wet, C.L., 2015, Preaching bondage: John Chrysostom and the discourse of slavery in early Christianity, University of California Press, Oakland, CA.

De Wet, C.L., 2018, The unbound God: Slavery and the formation of early Christian thought, Routledge, London.

DuBois, P., 2008, Slaves and other objects, University of Chicago Press, Chicago, IL.

Elm, S., 2017, '2016 NAPS presidential address: New Romans: Salvian of Marseilles On the Governance of God', Journal of Early Christian Studies 25(1), 1-28. https://doi. org/10.1353/earl.2017.0000

Gaca, K.L., 2003, The making of fornication: Eros, ethics, and political reform in Greek philosophy and early Christianity, University of California Press, Berkeley, CA

Glancy, J.A., 1998, 'Obstacles to slaves' participation in the Corinthian church', Journal of Biblical Literature 117(3), 481-501. https://doi.org/10.2307/3266444

Glancy, J.A., 2006, Slavery in early Christianity, Fortress, Minneapolis, MN.

Goffart, W., 2009, 'Salvian of Marseille, De gubernatione dei 5.38-45 and the "colonate" problem', Antiquité Tardive 17, 269-288. https://doi.org/10.1484/J.AT.3.44

Grubbs, J.E., 1999, Law and family in late antiquity: The emperor Constantine's marriage legislation, Oxford University Press, Oxford.

Grubbs, J.E., 2002, Women and the law in the Roman empire: A sourcebook on marriage, divorce and widowhood, Routledge, London.

Harper, K., 2011, Slavery in the late Roman world, AD 275-425, Cambridge University Press, Cambridge.

Harper, K., 2013, From shame to sin: The Christian transformation of sexual morality in late antiquity, Harvard University Press, Cambridge, MA.

Heather, P., 2006, The fall of the Roman empire: A new history of Rome and the barbarians, Oxford University Press, Oxford.

Hersch, K.K., 2010, The Roman wedding: Ritual and meaning in antiquity, Cambridge University Press, Cambridge.

Kartzow, M.B., 2018, The slave metaphor and gendered enslavement in early Christian discourse: Double trouble embodied, Routledge, London.

Kiefer, O., 2012, Sexual life in ancient Rome, Routledge, London.

Knust, J.W., 2006, Abandoned to lust: Sexual slander and ancient Christianity, Columbia University Press, New York.

Kuefler, M., 2001, The manly eunuch: Masculinity, gender ambiguity, and Christian ideology in late antiquity, University of Chicago Press, Chicago, IL.

Lagarrigue, G. (ed.), 1971, Salvien de Marseille: Oevres, Sources chrétiennes 176, Cerf, Paris.
Lagarrigue, G. (ed.), 1975, Salvien de Marseille: Oevres, Sources chrétiennes 220, Cerf, Paris.

Laiou, A.E., 1993, 'Sex, consent, and coercion in Byzantium', in A.E. Laiou (ed.), Consent and coercion to sex and marriage in ancient and medieval societies, pp. 109-226, Dumbarton Oaks, Washington, DC.

Maenchen-Helfen, O., 1973, The world of the Huns: Studies in their history and culture, University of California Press, Berkeley, CA.

Martin, D.B., 1990, Slavery as salvation: The metaphor of slavery in Pauline Christianity, Yale University Press, New Haven, CT.

McEleney, N.J., 1974, 'The vice lists of the pastoral epistles', The Catholic Biblical Quarterly 36(2), 203-219.

McGinn, T.A.J., 1998, Prostitution, sexuality, and the law in ancient Rome, Oxford University Press, Oxford.

McKeown, N., 2007, The invention of ancient slavery?, Duckworth, London.

Migne, J.-P., (ed.), 1845, Patrologiae cursus completus: Series ecclesiae Latinae, 217 vols., J.-P. Migne, Paris.

Migne, J.-P. (ed.), 1862, Patrologiae cursus completus: Series Graeca, 162 vols., J.-P. Migne, Paris.

Opelt, I., 1974, 'Antikes bildungsgut bei Salvian von Marseille', Vigiliae Christianae 28(1), 54-61. https://doi.org/10.2307/1583603

O'Sullivan, J.F. (transI.), 1962, The writings of Salvian, the presbyter, Catholic University of America Press, Washington, DC.

Perry, M.J., 2013, Gender, manumission, and the Roman freedwoman, Cambridge University Press, Cambridge.

Pruche, B. (ed.), 2013, Basile de Césarée: Sur le Saint-Esprit, Sources chrétiennes 17 Cerf, Paris.

Roisman, J., 2014, 'Greek and Roman ethnosexuality', in T.K. Hubbard (ed.), A companion to Greek and Roman sexualities, Blackwell Companions to the Ancient World, pp. 398-416, Wiley Blackwell, Malden, MA.

Samson, R., 2002, 'Slavery, the Roman legacy', in J. Drinkwater \& H. Elton (eds.) Fifth-century Gaul: A crisis of identity? pp. 218-227, Cambridge University Press, Cambridge.

Sanford, E.M. (transl.), 1930, Salvian: On the Government of God, Columbia University Press, New York, NY.

Scheidel, W., 1997, 'Quantifying the sources of slaves in the early Roman Empire', Journal of Roman Studies 87, 156-169. https://doi.org/10.1017/ S0075435800058123

Sessa, K., 2018, Daily life in late antiquity, Cambridge University Press, Cambridge.

Vecchi, G., 1951, Studi Salvianei I, Studi pubblicati dall' istituto di filologia classica 4 C. Zuffi, Bologne.

Vögtle, A., 1936, Die Tugend- und Lasterkataloge im Neuen Testament: Exegetisch, religions- und formgeschichtlich Untersucht, Aschendorff, Münster. 